DOI: https://doi.org/10.31933/jemsi.v2i6 Received: 8 Juni 2021， Revised: 17 Juli 2021, Publish: 7 Agustus 2021

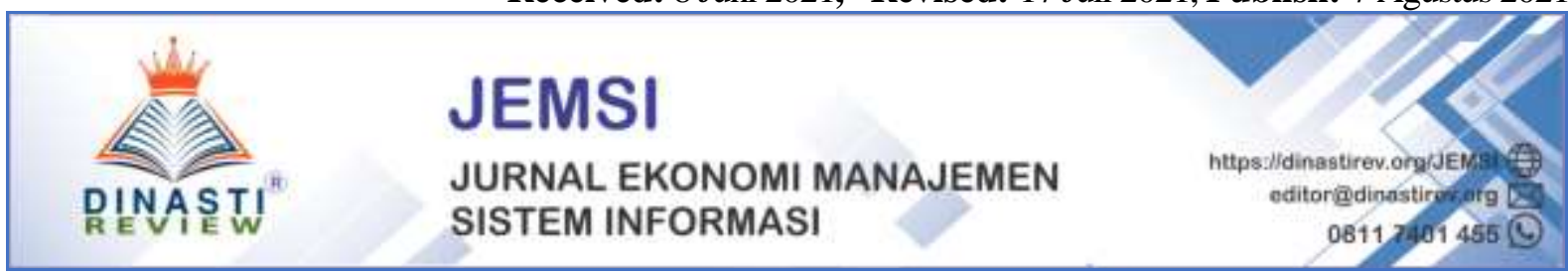

\title{
ANALISIS PERENCANAAN SUPPLY CHAIN MANAGEMENT (SCM) PADA PT. KYLO KOPI INDONESIA
}

\author{
Harto Maret Wijaya' ${ }^{1)}$, Ganif Deswantoro ${ }^{2)}$, Restu Hidayat ${ }^{3)}$ \\ ${ }^{1)}$ Pasis Dikreg Seskoal Angkatan 59, hartomaret.dikreg59seskoal@gmail.com \\ ${ }^{2}$ Dosen Pembimbing Seskoal \\ ${ }^{3)}$ Dosen Pembimbing Seskoal
}

\begin{abstract}
Abstrak: Perkembangan penjualan makanan dan minuman tumbuh dengan pesat. Salah satu minuman yang memiliki penjualan yang mengalami kenaikan yang besar adalah kopi. Dengan potensi berkembangan nya penjualan kopi, maka untuk memiliki keunggulan dalam persaingan penjualan Pt. Kylo Kopi Indonesia perlu menerapakan Supply Chain Management. Tujuan menggunakan Supply Chain Management, dimana yang paling dasar adalah bisa menyelaraskan pemintaan dengan pasokan yang ada. Metode penelitian ini adalah metode kualitatif yang focus pada analisis penerapan Supply Chain Management pada PT. Kylo Kopi Indonesia. Hasil penelitian ini adalah proses pemilihan pemasok di PT. Kylo Kopi Indonesia melalui Kerjasama denga vendor tunggal pemasok kopi yaitu Rekayasa Kopi. Perencanaan logistic pada Rekayasa Kopi termasuk terbaik dari segi kualitas produk, harga yang kompetitif dan kredibilitas perusahaan pemasok. Pasokan kopi dari Rekayasa Kopi ke pada PT. Kylo Kopi Indonesia sangat membantu pendistribusian pasokan kopi ke outlet-outlet PT. Kylo Kopi Indonesia dan berdampak kepada penjulanan minuman kopi.
\end{abstract}

Kata kunci: pemilihan pemasok, perencanaan, distribusi, SCM (supply chain management)

\section{PENDAHULUAN}

Kopi merupakan sejenis minuman yang berasal dari proses pengolahan biji tanaman kopi. Kopi digolongkan ke dalam famili Rubiaceae dengan genus Coffea. Secara umum kopi hanya memiliki dua spesies yaitu Coffea arabica dan Coffea robusta (Saputra E., 2008). Kopi 
dapat digolongkan sebagai minuman psikostimulant yang akan menyebabkan orang tetap terjaga, mengurangi kelelahan, dan memberikan efek fisiologis berupa peningkatan energi (Bhara L.A.M., 2005).

Di era globalisasi ini peminat pada minuman kopi semangkin meningkat sehingga banyak bermunculan outlet-outle kopi yang tersebar di seluruh Indonesia, sehingga membuat persaingian bisnis dibidang industri ini semakin ketat dan menuntut perusahaan untuk menyusun kembali startegi. Salah satu cara untuk bertahan di persaingan dalam era globalisasi ini adalah menerapkan supply chain management pada perusahaan nya. PT. Kylo Kopi Indonesia sebagai salah satu yang bergerak dalam industri minuman kopi perlu dimondernisasi dengan menerapakan supply chain management, seperti bantuan dalam berbagai tool manajemen operasional yaitu analisis logistik pemilihan pemasok seperti dalam penelitian ini. Logistik yang dimaksud dalam penelitian ina adalah kopi yang didistribusi oleh Rekayasa kopi kepada PT. Kylo Kopi Indonesia.

Logistik didefinisikan sebagai Proses pengelolaan yang strategis terhadap pemindahaan dan penyimpanan barang, suku cadang dan barang jadi dari supplier, di antara fasilitas-fasilitas perusahaan dan kepada para pelanggan. Bowersox (2006:13). Logistik adalah proses yang terorganisasi dimana mengatur aliran barang dagangan dari sumber Pasok ke vendor, pengrosir atau distributor melalui fungsi proses internal, sampai barang dagangan terjual dan sampai ke tangan pelanggan. (Levi \& Weitz, 2002:329).

Manajemen Logistik didefinisikan sebagai Proses pengelolaan yang strategis terhadap pemindahaan dan penyimpanan barang, suku cadang dan barang jadi dari supplier, di antara fasilitas-fasilitas perusahaan dan kepada para langganan. (Bowersox, 2006:13). Logistik adalah proses yang terorganisasi dimana mengatur aliran barang dagangan dari sumber Pasok ke vendor, pengrosir atau distributor melalui fungsi proses internal, sampai barang dagangan terjual dan sampai ke tangan pelanggan. (Levi \& Weitz, 2002:329)

Pemilihan pemasok logistik menurut Gencer dan Gurpinar (dalam Kurniawati, dkk, 2013:25), faktor kesuksesan perusahaan salah satunya adalah pemilihan pemasok. Pemasok yang dipilih dengan tepat dapat menjamin ketersediaan bahan baku untuk menjaga lintasan produksi. Memilih pemasok merupakan masalah multi kriteria dimana setiap kriteria digunakan mempunyai kepentingan berbeda dan informasi mengenai hal tersebut tidak diketahui dengan tepat. Pemilihan pemasok berdasarkan penawaran harga yang paling rendah sudah tidak efektif dan efisien lagi. Untuk mendapatkan kinerja rantai pasokan yang maksimal harus 
menggabungkan faktor lainnya yang sesuai dan selaras dengan tujuan perusahaan. Pemilihan pemasok yang tepat tidak hanya pemasok yang dapat memberikan material yang berkualitas, tepat waktu, dan harga terjangkau namun juga harus memberikan service yang optimal baik dari segi responsif, kelancaran komunikasi dan informasi. (Yoserizal dan Singgih, 2012:75). Perencanaan logistik merupakan dasar aktifitas manajemen yang lain. Dalam kegiatan perencanaan ini dilakukan proses analisis, pemikiran, penelitian dan perhitungan dalam upaya memenuhi kebutuhan-kebutuhan logistik. Untuk itu diperlukan sumber daya manusia yang mumpuni di bidang perencanaan logistik ini sehingga dapat mengambil keputusan secara tepat dan cepat. Setelah perencanaan dilakukan, maka tindakan selanjutnya yang harus dilakukan oleh manajer dan staf logistik adalah melaksanakan proses pengadaan barang/ jasa yang dibutuhkan. Banyak metode pengadaan barang yang dapat dipilih, misalnya: peminjaman, sewa, kontrak atau pembelian. Cara dan proses yang seperti apa yang perlu diambil oleh unit logistik sangat dipengaruhi oleh kemampuan dan kondisi organisasi/ perusahaan masing-masing. (Sulistio, 2012:5).

Perencanan logistik adalah merencanakan kebutuhan logistik yang pelaksanaannya dilakukan oleh semua calon pemakai (user) kemudian diajukan sesuai dengan alur yang berlaku di setiap organisasi. (Mustikasari, 2007:4).

Pendistribusian logistic menurut Kotler dan Keller (2009:106), saluran distribusi logistik adalah suatu perangkat organisasi yang tergantung yang tercakup dalam proses yang membuat produk atau jasa menjadi untuk digunakan atau dikonsumsi oleh konsumen atau pengguna bisnis. Warren J Keegan (2003:86), Saluran Distribusi adalah saluran yang digunakan oleh produsen untuk menyalurkan barang tersebut dari produsen sampai ke konsumen atau pemakai industri.

Istilah supply chain management dan logistik sering membingungkan atau digunakan secara bergantian, namun sebenarnya keduanya berbeda. Logistik adalah komponen dari manajemen rantai pasokan. Ia berfokus pada pemindahan produk atau material dengan cara yang paling efisien sehingga tiba di tempat yang tepat pada waktu yang tepat. Sebaliknya, SCM melibatkan serangkaian kegiatan yang lebih luas, mulai dari mencari sumber bahan baku, memperoleh barang dan bahan baku dengan harga terbaik, dan mengoordinasikan upaya visibilitas di seluruh jaringan rantai pasokan.

supply chain management sendiri merupakan pengelolaan dan juga pengawasan rantai siklus mulai dari bahan material atau barang mentah, pembayaran, informasi dari pemasok ke 
produsen, pedagang grosir pengecek sampai dengan konsumen. supply chain management merupakan usaha yang luas dan kompleks yang bergantung pada setiap mitra - dari pemasok hingga produsen dan seterusnya supaya dapat berjalan dengan baik. Tujuan dari manajemen rantai pasokan sendiri adalah untuk memaksimalkan nilai pelanggan dan mendapatkan keunggulan kompetitif di pasar. Untuk mencapainya, dibutuhkan berbagai upaya, baik strategi bisnis dan perangkat lunak khusus.

Proses-Proses dalam Supply Chain Management adalah

- Perencanaan

Ada beberapa aktivitas yang dilibatkan dalam tahap perencanaan, mulai dari prakiraan permintaan konsumen, perencanaan pembelian, dan perencanaan produksi, hingga persiapan tenaga kerja dan transportasi.

- Pembelian atau Pengadaan

Proses pengadaan biasanya melibatkan beberapa tahap, yakni pengajuan pembelian, penilaian pengajuan, persetujuan pembelian, dan pemesanan ke pemasok. Admin bertanggung jawab untuk memeriksa dan mencatat apa saja yang harus dibeli dan kemudian mengajukannya kepada manajer pembelian.

- Produksi

Proses produksi merupakan proses di mana seluruh bahan baku akan diolah menjadi produk jadi. Proses ini biasanya tidak hanya melibatkan tenaga kerja manusia tetapi juga mesin.

- Pengelolaan Gudang

Setelah barang selesai diproduksi, maka barang tersebut harus di simpan di dalam gudang. Pengelolaan gudang terdiri dari proses memasukkan (inbound) dan mengeluarkan (outbound) barang, pengambilan dan pengepakan, cross-docking, dan stock opname. Setiap barang yang masuk dan keluar harus selalu dicatat. Stock opname juga harus dilakukan secara berkala agar tidak ada perbedaan antara jumlah fisik barang yang sebenarnya dan jumlah barang yang tercatat dalam pembukuan. Seluruh aktivitas di gudang yang memakan waktu ini dapat diotomatiskan dengan bantuan warehouse management software

- Pengiriman Pesanan

Setelah barang pesanan diambil dari gudang dan dikemas, maka langkah selanjutnya adalah mengirimnya ke pelanggan. Kurir dan transportasi harus dipersiapkan terlebih dahulu agar barang dapat segera dikirim. 
- Pengembalian Pesanan

Pengembalian pesanan biasanya terjadi ketika konsumen mengajukan pengembalian yang dikarenakan kerusakan, kekeliruan, atau keterlambatan. Proses ini melibatkan beberapa aktivitas seperti pemeriksaan kondisi produk, otorisasi pengembalian, penggantian produk, dan penjadwalan pengiriman, pengembalian uang.

Ada beberapa tujuan menggunakan supply chain management, dimana yang paling dasar adalah bisa menyelaraskan pemintaan dengan pasokan yang ada. Selain itu ada beberapa hambatan atau masalah yang sering dialami saat menjalankan rantai pasokan seperti manajemen pengadaan barang, manajemen pemasok, mengelola hubungan dengan pelanggan, identifikasi masalah dan kemudian merespons masalah tersebut, manajemen risiko, dan lain sebagainya. Agar bisa menjadi pemenang dalam rantai pasokan penting bagi rantai pasokan untuk bisa menyediakan produk yang tidak hanya murah, namun berkualitas, bervariasi, dan juga disediakan tepat waktu.

Fungsi yang pertama adalah supply chain management secara fisik dimana fungsi dari supply chain management ini adalah mengonversi bahan baku menjadi produk jadi yang bisa disampaikan ke konsumen akhir. Fungsi utama dari supply chain management ini adalah berhubungan dengan berbagai macam biaya-biaya fisik berupa biaya material, biaya penyimpanan, biaya khusus produksi, biaya untuk transportasi, dan lain sebagainya.

Fungsi selanjutnya adalah supply chain management sebagai mediasi pasar dan memastikan jika telah di suplai oleh supply chain. Fungsi terakhir adalah berhubungan dengan biaya survei pasar, perencanaan produk, dan berbagai macam biaya yang bisa muncul akibat tidak terpenuhi aspirasi konsumen oleh produk yang mana disediakan oleh supply chain.

\section{METODE PENELITIAN}

\section{A. Metode Penelitian}

Dalam pelaksanaan penelitian ini perhitungan statistik menggunakan metode kualitatif karena metode penilitian yang digunakan menilite pada kondisi yang alamiah dimana peneliti sebagai instrument kunci. Penelitian kualitatif dimulia dengan pengumpulan informasiinformasi dalam situasi sewajarnya, untuk dirumuskan menjadi suatu genaralisasi yang dapat diterima oleh akal sehat manusia (sugiyono 2010:205). Informan penelitian adalah orang orang yang mengetahui atau pelaku yang terlibat langsung dengan permasalahanpenelitian ini. 
Penepatan informan ditentukan berdasarkan kajian penelitian yaitu pihak PT. Kylo Kopi Indonesia.

\section{B. Tujuan Penelitian}

Tujuan dari penelitian ini adalah untuk mengetahuai proses pemilihan pemasok, perencanaan logistic, dan pendistribusian logistik pada PT. Kylo Kopi Indonesia.

\section{Cara Pengumpulan Data}

Cara pengumpulan data pada penelitian ini adalah dengan melakukan wawancara. Wawancara adalah pertemuan yang dilakukan oleh dua orang untuk bertukar informasi maupun suatu ide dengan cara tanya jawab, sehingga dapat dikerucutkan menjadi sebuah kesimpulan atau makna dalam topik tertentu. Dalam hal ini penulis melakukan wawancara pada hakikatnya untuk memperoleh pemahaman secara holistic (secara menyeluruh) mengenai pandangan atau perspektif (konteks sistem dan persepsi visual) secara langsung kepada responden untuk membahas tentang permasalahan yang dihadapi dalam pelaksanaan tugas pendistribusian kopi.

\section{Teknik Analisi Data}

Menurut (sugiyono, 2010: 243) Data yang telah terkumpul, dianalisis dengan menggunakan Langkah-langkah yang sering disebut triangulasi, yaitu :

1) Redusi Data

2) Display Data

3) Kesimpulan

\section{E. Penelitian Terdahulu}

1) Penilitian Utami, dkk (2011), Penelitian ini bertujuan untuk mengetahui implementasi dari manajemen logistik kantor pada PMI Surakarta. Metode penelitian menggunakan metode kualitatif. Hasil penelitian menunjukan bahwa organisasii menerapkan manajemen logistic namun dilapangan masih kekurangan sumber daya manusia dan terlalu banyak fungsi dari pergudangan dan manemen kantor. Untuk itu diperlukan pemerdayakan sumber daya manusi dan peningkatan model logistic.

2) Penelitian Irani dan Hermawan (2012), Penelitian ini bertujuan adalah untuk menganalisis pemilihan supplier dan metode yangdigunakan adalah ANP (Analytic Network Process). Hasil dari penelitian ini menunjukan bahwa pemasok Bandung 
Indah Gemilang (BIG) memiliki bobot yang paling besar dan paling layak dijadikan Supplier untuk perusahaan.

3) Penelitian Budiman (2013), Keunggulan optimasi dan intergrasi Supply Chain menjadi fokus dari beberapa organisasi perusahaan besar yang ada di dunia. Implementasi Supply Chain merupakan salah satu bagian penting untuk memperbaiki kemampuan kompetisi organisasi bisnis. Upaya yang dapat ditempuh adalah merancang dan membuat alternatif agar dapat meminimalisir waktu, biaya, dan memaksimalkan proses. Pengumpulan data menggunakan metode penelitian kualitatif yaitu melakukan prosedur pengumpulan data melalui wawancara serta dokumentasi berdasarkan observasi dan dengan metode snowball sampling. Sumber data penelitian adalah UD Maju Jaya sebagai salah satu produsen daging ayam di kota Manado.

4) Penelitian Chandra (2013), penelitian ini bertujuan untuk mendukung kinerja manajemen rantai pasok dengan menerapkan sistem logistic. Metode dalam penelitian menggunakan metode kualitatif. Hasil penelitian menyimpulkan bahwa perusahaan dapat lebih efisiensi dan efektif apabila kinerja dari manajemen logistic mendukung peningkatan positif pada perusahaan.

\section{HASIL PENELITIAN DAN PEMBAHASAN}

\section{A. Hasil Wawancara}

Wawancara dilakukan pada informan penelitian yang terdiri dari pihak manajemen, Karyawan pada PT. Kylo Kopi Imdonesia. Model logistik kopi di PT. Kylo Kopi Indonesia mulai dari pabrik sampai ke perusahaan dapat dilihat Gambar 1

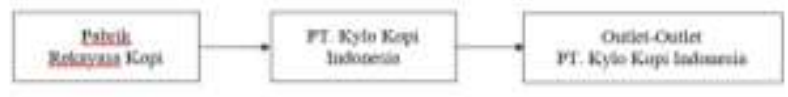

Gambar 1 Logistik Basic dari Rekayasa Kopi

Gambar 1 menjelaskan bahwa kopi yang digunakan langsung dikirim ke rekayasa kopi yang merupakan agen atau vendor tunggal yang mendistribusikan kopi ke PT. Kylo Kopi Indonesia. Dengan menunjuk hanya satu agen atau vendor kelebihanya adalah harga kompetitif, kualitas produk yang asli dan terjamin, sedangkan kelemahnya adalah tidak adanya alternatif pemasok lain. Untuk memperoleh dan merencanakan pasokan logistic 
tersebut ditentukan oleh kebutuhan dan analisis dari direktur operasional, Manajer pemasaran dam sales

Berikut alur logistik kopi sampai ke outlet-outlet PT. Kylo Kopi Indonesia.

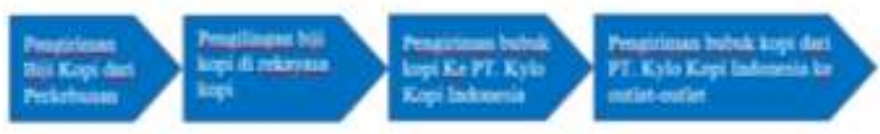

Gambar 2 Logistik Rekayasa Kopi ke Konsumen

Gambar 2, Menjelaskan mulai dari bahan mentah (biji Kopi) dari perkebunan kopi dikirim ke rekayasa kopi dimana bahan mentah (biji kopi) tersebut melakukan tahap proses pengilingan dari biji kopi menjadi bubuk kopi yang dimana bubuk kopi tersebut seterus nya dikirim ke PT. Kyo Kopi Indonesia dan selanjutnya akan distribusikan ke outlet-outle untuk dijual ke kosumen.

\section{B. Pembahasan}

\section{1) Pemilihan Pemasok}

Proses pemilihan pemasok bertujuan untuk menentukan pemasok yang tepat agar dapat memenuhi kebutuhan perusahaan, sehingga meminimasi risiko kurangnya persediaan. Pemilihan pemasok merupakan aktivitas penting dibagian pengadaan untuk mencapai keunggulan bersaing. Pemilihan pemasok berkaitan dengan banyak faktor, dimana setiap faktor digunakan untuk kepentingan berbeda dan informasi kebanyakan tidak diketahui secara pasti dan tepat. Untuk mendapatkan pemilihan pemasuk yang maksimal harus mencari kriteria-keteria lain yang relevan dengan tujuan persuhaan. Pemilihan pemasok bersifat banyak kriteria meliputi faktor kualitas dan kuantitas seperti kulitas pengiriman, kinerja masa lalu, garansi, harga, kemampuan Teknik, dan kondisi finansial. Pemilihan pemasok yamg tepat dapat memberikan bahan baku yang berkualitas, hatga yang terjangkau, serta ketepatan waktu pengiriman ditambahkan juga faktor kriteria harga, layanan, ketepatan pengiriman dan kepercayaan sebagai dasar memilik pemasok.

PT. Kylo Kopi Indonesia merupakan perusahaan yang bergerak di bidang industri makan dan minuman, khusunya minuman kopi yang dimana menjual minuman kopi dan menjual bubuk kopi juga. Perusahaan ini memperoleh distribusi logistik kopi dari Rekayasa 
Kopi. Pemilih pemasok dalam penelitian ini berdasarkan hasil penelitian bahwa pemasok PT. Kylo Kopi Indonesia untuk logistic kopi sejak awal sudah melalui Rekayasa Kopi yang merupakan salah satu pemasok kopi yang terbaik dari segi kualitas dan harga.

Cara mendatangkan pesenan logistic kopi dipesan sesuai dengan kebutuhan selama beberapa bulan namun untuk pesanan mendadak juga bisa dilakukan, jika terjadi kelebihan permintaan dan persediaan atau stock kopi habis, yaitu dengan memesan langsung dan menunggu beberap hari.

PT Kylo Kopi Indonesia sejak awal tidak mencari alternatif pemasok lainya khususnya yang berkualitas dibawah produk rekayasa kopi untuk mencegah kualitas rendah ataupun kualitas yang diragukan. Perusahaan juga tidak menyediakan kopi yang berkualitas rendah.

Pemilihan pemask pada penilitian ini sudah sangat baik dan unggul dari segi kualitas, jika dibandingkan dengan penelitian terdahulu oleh Budiman (2013) bahwa kondisi rantai pasok yang dipakai terlalu banyak dan tidak efisiensi dan memakai banyak biaya.

\section{2) Perencanaan Logistik}

Perencanaan logistik merupakan kegiatan pemikiran, penelitian, perhitungan, dan perumusan tindakan-tindakan yang kan dilakukan di masa yang akan datang, baik berkaitan dengan kegiatan-kegiatan operasional dalam pengadaan logistik, penggunaan logistik, pengorganisasian, maupun penegendalian logistik. Dengan demikian maka secara sederhana perencanaan logistic ini dapat diartikan sebagai proses perumusahan kebutuhan-kebutuhan logistic yang akan digunakan pada masa yang akan datang untuk mendukung tercapinya tujuan organisasi perusahaan scara efektif dan efiisiensi.

Perumusan kebutuhan logistik ini didahului oleh usulan dari berbagai unit kerja yang ada. Dalam proses perencanaan ini setidak-tidaknya harus mampu menjawab berbagi pertanyaan seperti :

a) Barang apa yang akan diadakan?

b) Mengapa barang itu perlu diadakan?

c) Kapang barang tersebut akan dibutuhkan?

d) Kapan barang itu akan diadakan?

e) Dimana barang tersebut dapat diperoleh?

f) Siapa yang akan menggunakanbarang-barang tersebut ?

g) Siapa yang bertanggung jawab melakukan pengadaan barang ?

h) Seberapa banyak barang itu dibutuhkan? 
i)Berapa harga barang-barang yang akan diadakan?

j)Bagaiman cara pengendalianbarang nya?

k) Bagaiamana prosedur pengadaan barang?

1)Bagaiman aturan-aturan tentang barang baik di internal organisasi maupun dari pihak lain?

Perecanaan logistic pada penelitian ini menekan pada proses perencanaan logistik yang berkualitas, dan jika dilihat pada perencanan logistic yang dijalankan PT. Kylo Kopi Indonesia sangat baik dilihat pengorganisasian maupun pengendalian logistic yang baik dibandingkan dengan penelitian terdahulu oleh utami, dkk (2011) yang menerapkan manajemen logistic namun di lapangan masih kekurangan sumber daya manusia, sehingga perencanaan logistic ini pada penelitian tersebut masih kurang baik dan perlu untuk dilakukan pemberdayaan sumber daya manusia.

\section{3) Pendistribusian Logistik}

Pendistribusian logistik adalah kegiatan pengiriman atau penyaluran barang dan jasa dari produsen ke konsumen. Pendistribusian logistik merupakan proses penyampaian secara efisien, efektif, aliran dan penyimpanan barang, jasa, dan informasi terkait titik asal ke titik konsumsi yang bertujuan untuk memenuhi kesesuain kebutuhan konsumen. Pendistribusian logistic dalam penelitian ini adalajh kegiatan mendistribusikan logistic kopi dari PT. Kylo Kopi Indonesia ke outlet-outle kopi.

Outlet-Outlet kopi sangat merasa puas terhadap kualitas dari kopi yang di distribusikan PT. Kylo Kopi Indonesia, karena selain kualitas kopi yang baik, pendistribusian logistic yang dilakukan oleh PT. Kylo Kopi Indonesia tidak pernah mengalami keterlambatan pasokan untuk ke outlet-outlet kopi.

\section{KESIMPULAN}

A. Pemilihan pemasok di PT. Kylo Kopi Indonesia melalui kerja sama penunjukkan langsung dengan principal agen tunggal Rekayasa Kopi untuk menyediakan logistic Kopi yang disini berupa bubuk kopi

B, Perencanaan logistik khususnya pengambilan keputusan manajemen untuk perencanaan logistik kopi di PT. Kylo Kopi Indonesia ditentukan oleh pihak manajemen seperti direktur, manajer operasional, manajer pemasaran, manajer sales serta manajer spare part. Sedangkan faktor yang berpengaruh terhadap perencanaan logistik yaitu kualitas produk dari pemasok, 
harga yang kompetitif, kredibilitas perusahaan pemasok, efisiensi waktu, efisiensi lokasi, serta efisiensi biaya.

C. Pendistribusian logistik dari PT.Kylo Kopi Indonesia dilakukan terpusat dimana pasokan setelah diterima dari Rakayasa Kopi kemudian didistribusikan ke outlet-outlet kopi Dalam mendistribusikan kopi ke outlet-outlet kopi juga dapat membantu konsumen dalam proses pembelian kopi..

\section{DAFTAR PUSTAKA}

[1] dan pengembangan Humaniora, Vol. 9 (2). http://jurnalpnj.comDiakses 6 February 2014. Hal. 97-103.

[2] Arikunto, S. 2010. Prosedur Penelitian: Suatu Pendekatan Praktik. Edisi Revisi 2010. Penerbit Rineka Cipta, Jakarta.

[3] Chandra, Afridel. 2013. Analisis Kinerja Distribusi Logistik Pada Pasokan Barang Dari Pusat Distribusi Ke Gerai Indomaret di Kota Semarang. Jurnal Institusional Repository. http://eprints.undip.ac.id/40234/. Diakses 21 February 2014. Hal. 15-24.

[4] Bowersox Donald J. 2002. Manajemen Logistik Terpadu. Penerbit Bumi Aksara, Jakarta.

[5] Budiman, E. V 2013. Evaluasi Kinerja Supply Chain pada UD. Maju Jaya di Desa Tiwoho Kabupaten Minahasa Utara. Jurnal Emba. Vol. 1(4). http://ejournal.unsrat.ac.id. Diakses 20 February 2014. Hal. 443-452.

[6] Danim, S. 2002. Menjadi Peneliti Kualitatif: Rancangan Metodologi. Presentasi dan Publikasi Hasil Penelitian untuk Mahasiswa dan Peneliti Pemula Bidang Ilmu-ilmu Sosial, Pendidikan dan Humaniora, Penerbit Pustaka Setia, Bandung.

[7] Heizer, J., \& Render, B. 2010. Manajemen Operasi. Edisi 7. Penerbit Salemba Empat, Jakarta.

[8] Irani, Y. \& Hermawan. 2012. Pemilihan Supplier Bahan Baku Benang dengan Menggunakan Metode Analytic Network Process (ANP) (Studi Kasus Home Industry Nedy). Simposium Nasional RPI XI FT UMS 2012. http://repository.widyatama.ac.id. Diakses 10 Maret 2014. Hal. 85-95.

[9] Kalakota, R. 2000. E-Business 2.0: Roadmap to Success. Longman: Addison Welley, USA. 
[10] Keegan, W. J. 2003. Manajemen Pemasaran Global. Edisi 6. Penerbit Prenhallindo, Jakarta.

[11] Kotler, P., \& Keller, K. 2009. Manajemen pemasaran. Edisi 13. Penerbit Erlangga, Jakarta.

[12] Kurniawati, D,.Yuliando, H,. \& Widodo, K,.2013. Kriteria Pemilihan Pemasok Menggunakan Analytical Network Process. Jurnal Teknik Industri. Vol. 15(1). http://puslit2.petra.ac.id/ejournal. Diakses 10 February 2014. Hal. 25-32.

[13] Levy, M. \& Weitz, B.A. 2002, Retail Management 6thed., McGraw-Hill., New York.

[14] Moleong, L. J. 2004. Metodologi Penelitian Kualitatif. Penerbit PT. Remaja Rosda Karya, Bandung.

[15] Mustikasari. 2007. Fungsi Manajemen Logistik. http://ondyx.blogspot.com.Diakses 23 February 2014. Hal.1-10

[16] Sulistio, E. 2012. Perencanaan dan Pengadaan Logistik. http://www.academia.edu/6429091/BAB_VII_Perencanaan_dan_Pengadaan_Logistik. Diakses 7 Maret 2014. Hal. 1-30.

[17] Simamora, B. 2008. Panduan Riset Perilaku Konsumen. Penerbit Gramedia, Jakarta.

[18] Sugiyono. 2010. Metode Penelitian Bisnis (Pendekatan Kuantitatif, Kualitatif dan R\&D). Penerbit Alfabeta, Bandung.

[19] Utami, N. A. P. U., Wagimin, Ign, dan Jumiyanto, W. 2011 Manajemen Perbekalan Kantor Palang Merah Indonesia. Pendidikan Administrasi Perkantoran. Vol.1(1). http://jurnal.fkip.uns.ac.id. Diakses 20 February 2014. Hal. 1-6.

[20] Yoserizal, Y, \& Singgih, M. L,. 2012. Integrasi Metode Dematel (Decision Making Trial and Evaluation Laboratory) dan ANP (Analytical Network Process) dalam Evaluasi Kinerja Supplier di PT. XYZ. Prosiding Seminar Nasional Manajemen Teknologi XV, ITS. Surabaya.http://personal.its.ac.id. Diakses 3 Maret 2014. Hal. 7178. 